\title{
UIT TYDSKRIFTE
}

\section{De Waarheidsvriend oor Kerkgeld vir Geweld.}

In De Waarheidsvriend (Jrg. 65, Nr. 33) spreek die redakteur, Ir. Van der Graaf, hom sterk uit teen die PCR (Program to combat racism) van die Wêreldraad van Kerke. Hy noem dit ,absoluut verwerplik", en verskaf daarby die informasie dat die afgelope jare, 1970-76, twee en 'n half miljoen rand aan hierdie program van die Wêreldraad vir die finansiering van terrorisme geskenk is. Hiervan het uit die kleine Nederland byna die helfte, nl. ongeveer R1,1 miljoen gekom, sewe keer soveel as uit die magtige en ryk Amerika, waar sewentien keer soveel mense as in Nederland woon. Ander lande waar die kerke ook ruim bygedra het, maar nie naastenby soveel as in Nederland nie, is Swede en Wes-Duitsland.

Dieselfde blad (Jrg. 66, Nr. 1) haal 'n artikel van prof. $H$. Jonker aan. Hy verwys na die suggestie van die moderamen op die Nederl. Herv. Sinode vanjaar dat die NHK in die toekoms moet skakel met die ANC, omdat die Christelike Instituut onlangs deur die SA owerheid verbied is. Prof. Jonker stel dan die vraag of dit nou die roeping van die kerk is. Hy haal aan uit die bekende "Getuigenis" van enkele jare gelede waarop die Sinode van die NHK tog positief reageer het:

„Ons Getuigenis richt zig met name tegen de hoogmoedige en onverdraagzame mentaliteit, die het Evangelie verbasterd tot puur aards messianisme. Tegen een onschriftuurlijke werkeli:kheid, die het christelijk geloof vereenzelvigt met een bepaalde maatschaplijke en politieke betrokkenheid. Tegen een moderne syncretisme, waarbij de belofte van het Koninkrijk Gods vermengd word met ideën, die hun oorsprong niet vinden in de Bijbel, maar in humanistiese en ateïstiese ideologieën. Tegen een verpolitisering en vermaatschappelijking van het Heil in de zin van een opstand tegen de gevestigde orde (het zgn. ,establishment') en een omverwerping van de huidige maatschappelijke en politieke orde en structuren!"

Jy kan Amos 8 nie lees sonder om ook na Amos 4 te luister nie, sê prof. Jonker.

Hy stel die vraag waarom daar nie liewer met die susterkerke in Suid-Afrika, veral die kerke onder die Swartes, Kleurlinge en Indiërs, kontak gemaak word nie.

Prof. Jonker betreur die uiterste opportunisme wat die motiewe van sekere sinodelede dra, nl. dat die kerke die ,bevrydingsbewegings" moet steun, want dan sal hulle gunstig gestem wees teenoor die kerke wanneer hulle aan bewind kom. Hy vra wat ons daarvan sou dink as die Bekennende Kirche in Duitsland daardie houding teenoor Hitler aangeneem het. 'n Mens kan nie help om te wonder wat in Mosambiek en Angola van hierdie vriendskap van Salomo met swaer Farao geword het nie!

Prof. Jonker sê dat volgens Art. 36 NGB die invloed van die kerk op die owerheid nie langs die weg van politieke druk nie, maar 
52 In die Skriflig

van voorbede moet gaan. Die kerk moet opkom vir die geregtigheid in die samelewing, maar dit beteken allermins dat dit eensydig kant moet kies in die politieke polarisasie van partye teen partye en van volk teen volk.

K. v. R. 